\title{
INCORPORATION OF NISIN IN NATURAL CASING FOR THE CONTROL OF SPOILAGE MICROORGANISMS IN VACUUM PACKAGED SAUSAGE
}

\section{Joyce Regina de Barros ${ }^{1}$; Leo Kunigk²; Cynthia Hyppolito Jurkiewicz ${ }^{2} *$}

${ }^{1}$ Faculdade de Tecnologia Termomecanica, São Bernardo do Campo, SP, Brasil; ${ }^{2}$ Instituto Mauá de Tecnologia, São Caetano do Sul, SP, Brasil.

Submitted: June 12, 2009; Returned to authors for corrections: April 04, 2010; Approved: May 30, 2010.

\begin{abstract}
This study aimed to evaluate the effectiveness of natural casing treatment with nisin and phosphoric acid on control of spoilage microorganisms in vacuum packaged sausages. Ovine casings were dipped in the following baths: 1) $0.1 \%$ food grade phosphoric acid; 2) $5.0 \mathrm{mg} / \mathrm{L}$ nisin; 3) $0.1 \%$ phosphoric acid and 5.0 $\mathrm{mg} / \mathrm{L}$ nisin; and 4) sterile water (control). The sausages were produced in a pilot plant, stuffed into the pretreated natural casings, vacuum packaged and stored at 4 and $10{ }^{\circ} \mathrm{C}$ for 56 days. The experiments were performed according to a full factorial design $2^{3}$, totalizing 8 treatments that were repeated in 3 blocks. Aerobic plate counts and lactic acid bacteria analysis were conducted at 1, 14, 28, 42 and 56 days of storage. Treatment of casings with phosphoric acid $0.1 \%$ alone did not inhibit the growth of lactic acid bacteria and reduced the aerobic plate count by $1 \mathrm{log}$. The activity of nisin against lactic acid bacteria was enhanced by the addition of phosphoric acid, demonstrating a synergistic effect. Furthermore nisin activity was more evident at lower storage temperature $\left(4^{\circ} \mathrm{C}\right)$. Therefore treatment of the natural casings with nisin and phosphoric acid, combined with low storage temperature, are obstacles that present a potential for controlling the growth of lactic acid bacteria in vacuum packaged sausage.
\end{abstract}

Key words: Nisin, Bacteriocin, Sausage, Natural casing

\section{INTRODUCTION}

In recent years, consumers are demanding for more convenient foods, minimally processed, with a fresh appearance, free of chemical additives, with an extended shelf life, but also safe. To prevent the growth of pathogens and reduce the microbial spoilage, a new alternative is biopreservation, based on the use of microorganisms and/or their metabolic products to inhibit the growth of undesired microorganisms in foods $(8,15)$.
Bacteriocins are antimicrobial peptides that are produced by gram-positive and gram-negative species of microorganisms. However only bacteriocins produced by foodgrade lactic acid bacteria are of particular interest to the food industry as biopreservatives (12). Nisin is a bacteriocin generally recognized as safe (GRAS) by the US Food and Drug Administration and World Health Organization since 1969. It is produced by certain strains of Lactococcus lactis subsp. lactis, and is commercially available for use in foods $(14,21)$. Nisin is a heat stable peptide, with 34 aminoacid residues, and

\footnotetext{
*Corresponding Author. Mailing address: Instituto Mauá de Tecnologia Engenharia Química e de Alimentos, Praça Mauá 1 - São Caetano do Sul, SP, Brasil 09580-900.; Tel/Fax.: 55-11-4396-2673.; E-mail: cynthia@maua.br
} 
a molecular weight of $3510 \mathrm{Da}$. It is classified as a lantibiotic, due to presence of lanthionine and $\beta$-methyllantionine residues in the molecule. These unusual residues form covalent bridges between amino acids, resulting in internal rings responsible for the characteristic structural features (8). Nisin is active against gram-positive bacteria, but is not effective against gramnegative, yeast and mold (20).

Nisin has been shown to be effective in controlling spoilage and pathogenic bacteria in many meat products $(6,7$, $16,19,23,24,26,34,36)$. However nisin activity may be affected by many factors, such as concentration, the target microorganisms, interaction with food components, fat content and phosphate type, processing and storage conditions of food $(5,10,35)$.

In minimally heat-treated, cured, vacuum-packaged and chilled meat products, such as Frankfurters and Vienna sausages, nisin can be applied to inhibit spoilage by lactic acid bacteria selected by the low storage temperature, presence of nitrite and curing salts, and microaerophilic conditions (10, 13).

As the growth of spoilage microbial population on vacuum packed cured meats occurs essentially on the surface of the products, the effectiveness of an antimicrobial treatment could be enhanced by applying the antimicrobial compound to the surface of the cooked meats (18). This could be achieved by dipping products in an antimicrobial bath (17), applying a spray (9), coating by an edible gel (11), or using a packaging system $(20,33)$. Moreover surface addition of bacteriocins facilitates distribution through the product and reduces interaction with meat component, improving the antimicrobial activity $(2,28)$.

In Brazil, nisin was authorized to be applied, by immersion or spraying, on the surface of frankfurters at the end of the thermal processing step at a level of $200 \mathrm{mg} / \mathrm{L}$ of Nisaplin ${ }^{\circledR}$ (commercial nisin preparation from Danisco), dissolved in $0.1 \%$ food grade solution of phosphoric acid (15).

In this study, a new alternative of applying antimicrobials to sausage surface was evaluated. Nisin, phosphoric acid and the combination of the two were incorporated to sausage natural casings, at the soaking step, and the effectiveness of these treatments for the control of lactic acid bacteria and total aerobic counts was evaluated during the storage of vacuum package sausages. The influence of storage temperature was also evaluated.

\section{MATERIALS AND METHODS}

\section{Natural casing preparation and its activity}

Ovine natural salted casing was provided by Kienast \& Kratschmer (Kraki, Brazil) and stored at $4{ }^{\circ} \mathrm{C}$. Before use, casings were washed and soaked for $2 \mathrm{~h}$ in potable water to remove the salt. Subsequently, casings were divided in 4 groups and each of them dipped for $1 \mathrm{~h}$ and $40 \mathrm{~min}$ in the

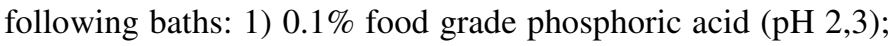
2) $5.0 \mathrm{mg} / \mathrm{L}$ nisin $(\mathrm{pH} \mathrm{4,6);3)} 0.1 \%$ phosphoric acid and 5.0 $\mathrm{mg} / \mathrm{L}$ nisin $(\mathrm{pH} \mathrm{2,3)}$; and 4) sterile water ( $\mathrm{pH} \mathrm{5,4).} \mathrm{Nisin} \mathrm{was}$ provided by Danisco, Brazil, in the form of the commercial product Nisaplin $®$ (Applin \& Barret) that contained 2.5\% pure nisin. The concentration of nisin $(5.0 \mathrm{mg} / \mathrm{L})$ used in this study corresponds to $200 \mathrm{mg} / \mathrm{L}$ Nisaplin®.

Nisin activity in the solutions and in the natural casings was monitored using the agar diffusion assay (30). Molten De Man, Rogosa \& Sharpe agar (MRS - Oxoid) was cooled to 45 ${ }^{\circ} \mathrm{C}$ and seeded with an overnight culture of the indicator microorganism, Lactobacillus sakei ATCC 15521. After agar solidification, wells ( $5 \mathrm{~mm}$ diameter) were cut using a sterile glass tube and $40 \mu \mathrm{L}$ of each solution were added to each well. Natural casings containing the antimicrobials were cut into circles (9 $\mathrm{mm}$ diameter) and also placed on the agar surface. Plates were stored at $4{ }^{\circ} \mathrm{C}$ for $1 \mathrm{~h}$ to allow the bacteriocin to diffuse into the agar, before incubation at $30^{\circ} \mathrm{C}$ for $24 \mathrm{~h}$. Nisin activity was observed as a zone of inhibition of the indicator microorganism around the wells and the casings. Inhibition radius was measured $(\mathrm{mm})$ from the edge of the well or the casing to the edge of the halo.

\section{Sausage production}

The sausages were produced in a pilot plant, according to 
the following composition: lean beef, 25.8\%; lean pork, 30.7\%; lard, 15.0\%; spices and additives, 1.0\%; sodium chloride, $2.0 \%$ and water, 25.5\%. Spices and additives were used as a commercial mixture (Sausage Mixture 314, Kienast \& Kratschmer, Kraki, Brazil) composed by sodium tripolyphosphate, sodium polyphosphate, sodium erythorbate, nitrite, nitrate, monosodium glutamate, natural spices and flavorings. The raw ground lean beef and fat were obtained in a local market and stored at $-18^{\circ} \mathrm{C}$ in a plastic bag. Ingredients were mixed (STEPHAN/GEIGER, UMMSK-25/40E) and during operation the temperature of the emulsion was maintained below $16^{\circ} \mathrm{C}$ by addition of crushed ice. The emulsion was stuffed into the pre-treated natural casings using a manual stuffer (MADO, MWF 591). The sausages were heat processed at $60{ }^{\circ} \mathrm{C}$ for $2 \mathrm{~h}$ and then cooked in steam bath for 15 min after the internal temperature reached $74{ }^{\circ} \mathrm{C}$. After cooking, the sausages were maintained in a cooling chamber for $24 \mathrm{~h}$, and then vacuum packed in bags (CRYOVAC Sealed Air Corporation) and stored at $4{ }^{\circ} \mathrm{C}$ or $10^{\circ} \mathrm{C}$ for 56 days.

\section{Microbiological analysis}

Aerobic plate counts and lactic acid bacteria analysis were conducted at 1, 14, 28, 42 and 56 days of storage. Sausage portions ( $25 \mathrm{~g}$ ) were aseptically weighed into a stomacher 400 bag (Seward Medical, London, UK) with $225 \mathrm{~mL}$ of $0.1 \%$ peptone water and homogenized for $1 \mathrm{~min}$. Serial dilutions were prepared in the same diluent and $1.0 \mathrm{~mL}$ was inoculated onto suitable media using the pour plate technique, in duplicates. Aerobic bacteria were cultivated on Plate Count Agar (Oxoid) at $36 \pm 1^{\circ} \mathrm{C}$ for $48 \mathrm{~h}$ (29). Lactic acid bacteria were enumerated on De Man Rogosa e Sharpe Agar (MRS, Oxoid), incubated at $32 \pm 1^{\circ} \mathrm{C}$ for $48 \mathrm{~h}$ in anaerobic system, Anaerogen, Oxoid (22). Mean values of bacterial counts were converted into $\log$ cfu.g ${ }^{-1}$.

\section{Experimental Design}

A $2^{3}$ factorial design (3) was applied to evaluate the effect of the three variables: (1) nisin, (2) phosphoric acid and (3) temperature. As response variables, the aerobic plate counts and lactic acid bacteria counts were determined during sausage storage. The levels assumed for the variables and the experimental design are presented in Table 1. Treatments were repeated in three blocks, totalizing 24 experiments.

Table 1. Experimental design

\begin{tabular}{cccc}
\hline Treatment & $\begin{array}{c}\left(\mathbf{X}_{\mathbf{1}}\right) \\
\text { Nisin }(\mathbf{m g} / \mathbf{L})\end{array}$ & $\begin{array}{c}\left(\mathbf{X}_{\mathbf{2}}\right) \\
\text { Phosphoric } \\
\text { acid }(\% \mathbf{w} / \mathbf{v})\end{array}$ & $\begin{array}{c}\left(\mathbf{X}_{3}\right) \text { Storage } \\
\text { temperature } \\
\left({ }^{\circ} \mathbf{C}\right)\end{array}$ \\
\hline 1 & 0 & 0 & 4 \\
2 & 0 & 0.1 & 4 \\
3 & 5 & 0 & 4 \\
4 & 5 & 0.1 & 4 \\
5 & 0 & 0 & 10 \\
6 & 0 & 0.1 & 10 \\
7 & 5 & 0 & 10 \\
8 & 5 & 0.1 & 10 \\
\hline
\end{tabular}

\section{Statistical analysis}

Results from $2^{3}$ factorial design were processed and analyzed using the software Minitab ${ }^{\text {TM }} 15$ (Minitab, Inc. State College, EUA). The statistical significance was determined by analysis of variance (ANOVA).

\section{RESULTS AND DISCUSSION}

\section{Agar diffusion assay}

Natural casing treated with nisin $(5.0 \mathrm{mg} / \mathrm{L})$ presented antimicrobial activity against Lactobacillus sakei ATCC 15521, although the inhibition halo $(0.9 \pm 0.3 \mathrm{~mm})$ was significantly smaller $(\mathrm{p}<0.05)$ when compared to the solution inhibition halo $(2.1 \pm 0.3 \mathrm{~mm})$. Casings treated with nisin $(5.0$ $\mathrm{mg} / \mathrm{L})$ in phosphoric acid solution $(0.1 \%)$ also presented an inhibitory activity, with no significant difference $(\mathrm{p}>0.05)$ between solution inhibition zone $(2.3 \pm 0.5 \mathrm{~mm})$ and casing inhibition zone $(3.3 \pm 0.6 \mathrm{~mm})$. The treatment of natural casing only with water or phosphoric acid resulted in no activity against the indicator microorganism.

Effect of nisin, phosphoric acid and temperature on bacterial growth

The effect of nisin, phosphoric acid and temperature on the average counts $\left(\log \mathrm{cfu} \cdot \mathrm{g}^{-1}\right)$ of total aerobes and lactic acid 
bacteria in sausages during 56 days of storage are presented in Table 2. In the first day, none of the variables affected significantly the bacterial growth, indicating that the addition of nisin and phosphoric acid did not result in an immediate antimicrobial activity.

The temperature was the variable that most significantly reduced the bacteria growth in sausages during storage. The highest effect values for this factor were obtained when compared to nisin and phosphoric acid effects (Table 2). At day 14 , total aerobic and lactic acid bacteria counts in sausages stored at $4^{\circ} \mathrm{C}$ were $3 \log \mathrm{cfu} \cdot \mathrm{g}^{-1}$ lower than in those stored at $10^{\circ} \mathrm{C}$. During storage the temperature effect values decreased and at day 56 only lactic acid bacteria counts were significant lower in sausages stored at $4^{\circ} \mathrm{C}$ than in those stored at $10^{\circ} \mathrm{C}$ by $0.5 \log \mathrm{cfu} \cdot \mathrm{g}^{-1}$ (Table 2). Figures 1 and 2 present the total aerobic and lactic acid bacteria counts in the sausages during storage at $4^{\circ} \mathrm{C}$, respectively. Figure 3 and 4 present the same microorganisms counts in sausages stored at $10^{\circ} \mathrm{C}$.

Table 2. Effect of nisin $\left(X_{1}\right)$, phosphoric acid $\left(X_{2}\right)$ and temperature $\left(X_{3}\right)$ on total aerobic plate counts (APC) and lactic acid bacteria $(\mathrm{LAB})$ counts in sausages during storage.

\begin{tabular}{lcccccccccc}
\hline & \multicolumn{2}{c}{1 day } & \multicolumn{2}{c}{ 14 day } & \multicolumn{2}{c}{ 28 day } & \multicolumn{2}{c}{ 42 day } & \multicolumn{2}{c}{56 day } \\
\cline { 2 - 11 } Term & APC & LAB & APC & LAB & APC & LAB & APC & LAB & APC & LAB \\
\hline $\mathrm{X}_{1}$ & -0.11 & 0.01 & $-0.60^{*}$ & -0.31 & $-0.88^{*}$ & $-0.87^{*}$ & -0.41 & -0.44 & 0.06 & -0.25 \\
$\mathrm{X}_{2}$ & -0.25 & 0.09 & $-0.50^{*}$ & -0.18 & $-0.73^{*}$ & -0.31 & $-0.95^{*}$ & -0.29 & -0.31 & -0.18 \\
$\mathrm{X}_{3}$ & 0.12 & -0.05 & $3.00^{*}$ & $2.94^{*}$ & $2.40^{*}$ & $2.24^{*}$ & $1.20^{*}$ & $1.20^{*}$ & 0.30 & $0.54^{*}$ \\
$\mathrm{X}_{1} \cdot \mathrm{X}_{2}$ & -0.16 & -0.25 & -0.21 & $-0.83^{*}$ & -0.18 & $-0.60^{*}$ & -0.16 & -0.45 & -0.09 & $-0.53^{*}$ \\
$\mathrm{X}_{1} \cdot \mathrm{X}_{3}$ & -0.01 & 0.07 & 0.00 & -0.19 & 0.18 & $0.52^{*}$ & 0.26 & 0.30 & 0.20 & 0.03 \\
$\mathrm{X}_{2} \cdot \mathrm{X}_{3}$ & -0.01 & -0.05 & 0.35 & -0.32 & $0.78^{*}$ & 0.28 & 0.09 & -0.11 & $-0.40^{*}$ & -0.28 \\
$\mathrm{X}_{1} \cdot \mathrm{X}_{2} \cdot \mathrm{X}_{3}$ & 0.12 & 0.07 & 0.18 & 0.63 & 0.51 & $0.85^{*}$ & -0.17 & 0.16 & -0.12 & -0.04 \\
\hline * Values that are significant $(\mathrm{p}<0.1)$. & & & & & & & & & &
\end{tabular}

* Values that are significant $(\mathrm{p}<0.1)$.

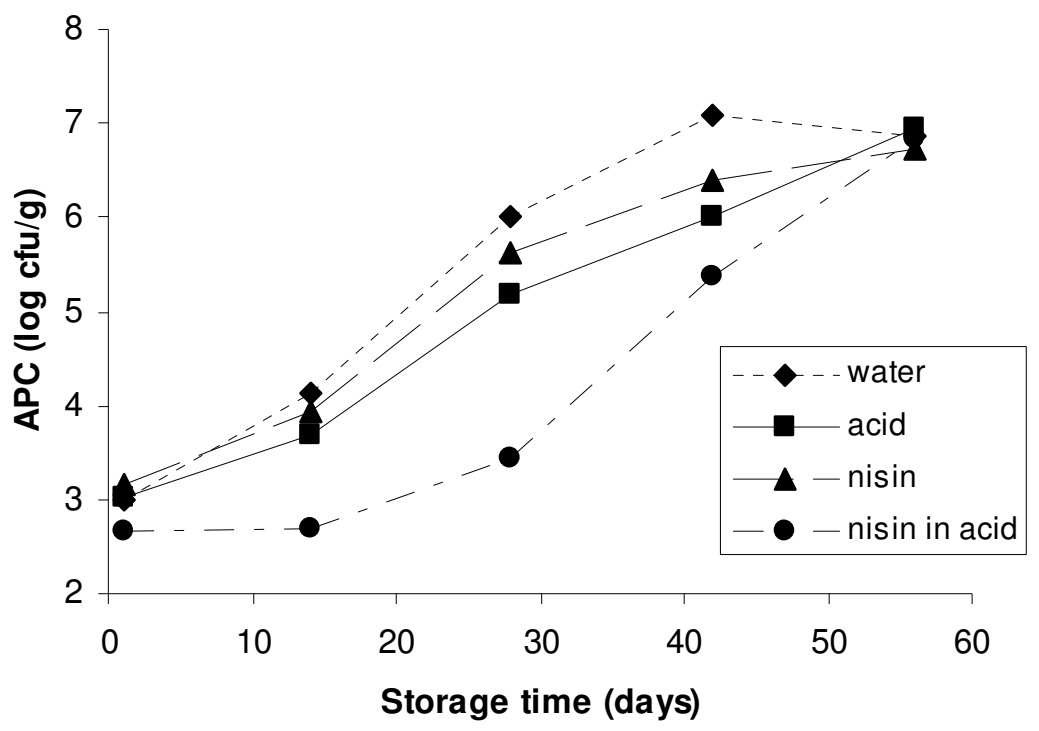

Figure 1. Aerobic plate counts in sausages with different treated casings during storage at $4{ }^{\circ} \mathrm{C}$. 


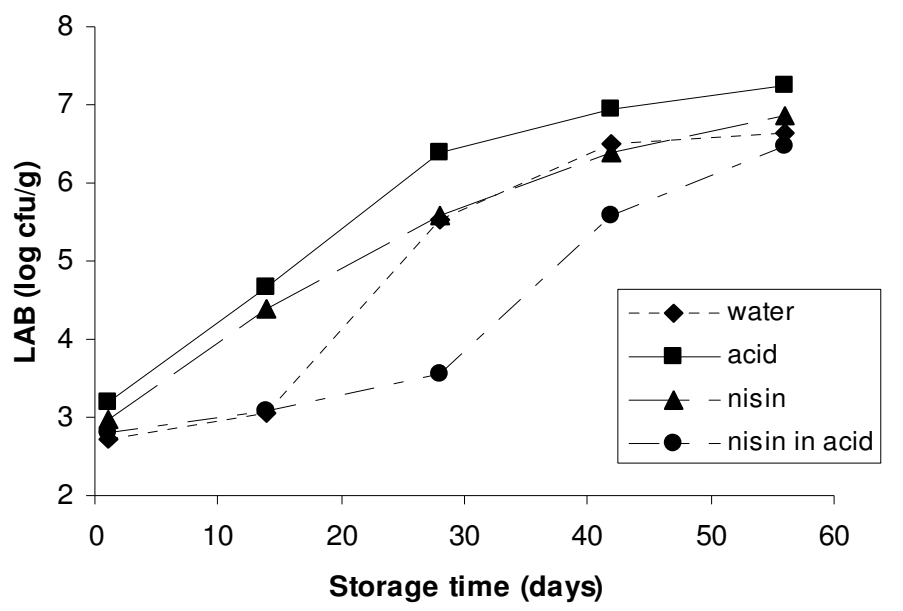

Figure 2. Lactic acid bacteria counts in sausages with different treated casings during storage at $4^{\circ} \mathrm{C}$.

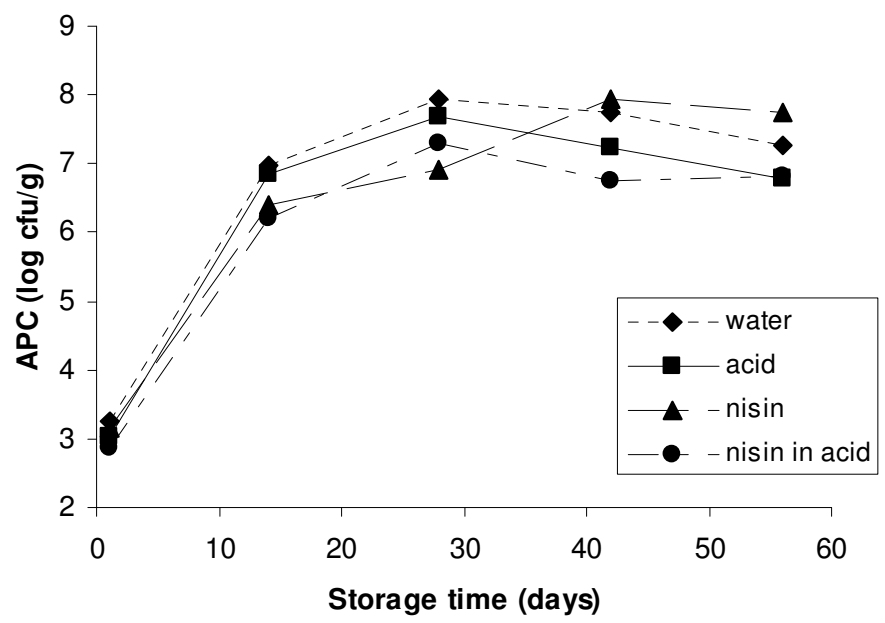

Figure 3. Aerobic plate counts in sausages with different treated casings, during storage at $10^{\circ} \mathrm{C}$.

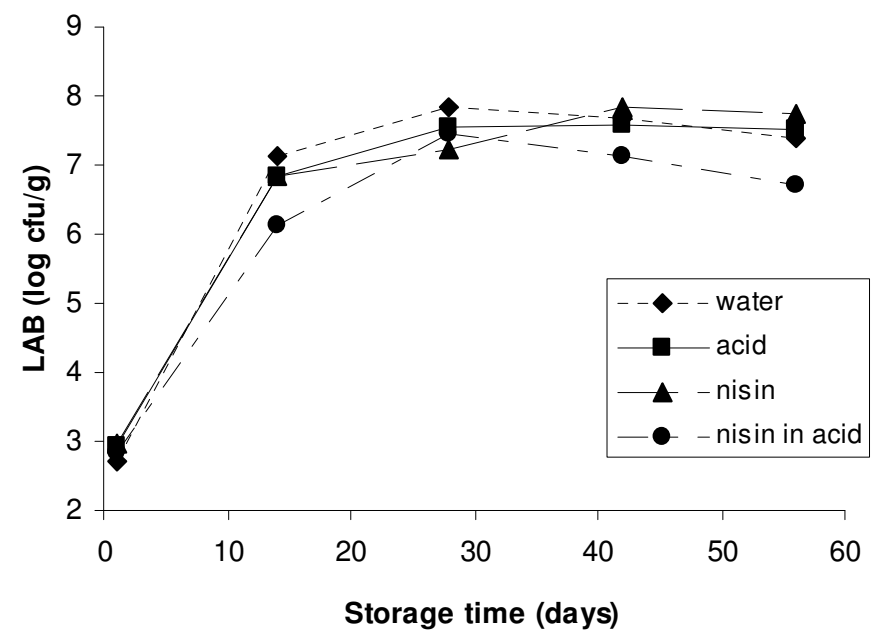

Figure 4. Lactic acid bacteria counts in sausages with different treated casings during storage at $10^{\circ} \mathrm{C}$. 
Phosphoric acid alone reduced significantly total aerobic counts during 42 days of storage. The maximum reduction by 1 $\log \mathrm{cfu} \cdot \mathrm{g}^{-1}$ in relation to sausages untreated with the acid was observed at day 28 and 42 for the products stored at $4{ }^{\circ} \mathrm{C}$ (Figure 1), and at day 28 for products stored at $10^{\circ} \mathrm{C}$ (Figure 3). However no significant reduction was observed in the number of lactic acid bacteria (Figures 2 and 4). This may be explained by the fact that lactic acid bacteria are more resistant to acid conditions caused by the natural casing treated with phosphoric acid solution ( $\mathrm{pH}$ 2.3). Ariyapipun et al. (1) found similar results using lactic acid on the surface of vacuum packaged fresh beef.

The natural casing treatment only with nisin did not significantly reduce lactic acid bacteria counts. It significantly decreased the aerobic plate counts only on days 14 and 28 of storage by 0.6 and $0.9 \log$ respectively (Table 2 ). The reduction of total aerobic counts in sausages treated with nisin may also be explained by the low $\mathrm{pH}$ of nisin solution $(\mathrm{pH} 4.3)$, since lactic acid bacteria was not affected. Sausages with casing treated with nisin in phosphoric acid solution presented the lowest aerobic plate counts during storage at $4{ }^{\circ} \mathrm{C}$ (Figure 1). The number of lactic acid bacteria was also lower in sausages treated with both antimicrobials (Figure 2). For these microorganisms, nisin and phosphoric acid showed a significant interaction on days 14, 28 and 56 (Table 2), indicating a synergistic effect. These data are in agreement with other authors, which demonstrated that the acid condition of the solution containing nisin may enhance the antimicrobial effect $(16,27)$. A significant interaction was observed between the three variables at day 28 for lactic acid bacteria counts (Table 2). For sausages stored at $4{ }^{\circ} \mathrm{C}$, the treatment with nisin in phosphoric acid solution reduced lactic acid count by $3 \log$ $\mathrm{cfu} \cdot \mathrm{g}^{-1}$, while treatment only with nisin had no inhibitory effect. However, at $10^{\circ} \mathrm{C}$, lactic acid bacteria counts were not influenced by nisin and phosphoric acid (Figure 5). The lower nisin activity at higher storage temperature could explain these results. Raju et al. (31) also demonstrated that loss of nisin activity in fish sausage was higher at ambient temperature than at refrigerated storage.

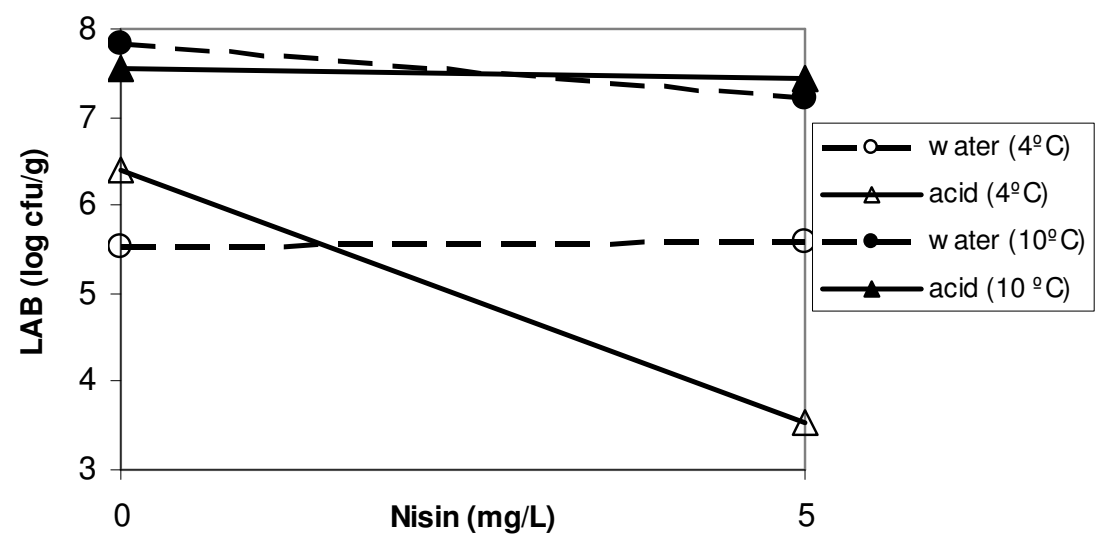

Figure 5. Interaction of nisin, phosphoric acid and temperature for lactic acid bacteria counts in sausages at $28^{\text {th }}$ day of storage at $4^{\circ} \mathrm{C}$ and $10^{\circ} \mathrm{C}$.

The results obtained in this study also showed that nisin remained active after the sausage cooking process, confirming the intrinsic thermotolerance, previously demonstrated by other authors $(33,35)$.
Lactic acid bacteria are frequently associated with spoilage of most heat processed meats (25). As shown in this study, the treatment of casings with nisin in phosphoric acid solution extended the shelf life of sausages stored at $4{ }^{\circ} \mathrm{C}$. The counts of 
lactic acid bacteria in non-treated sausages reached $10^{7} \mathrm{cfu} \cdot \mathrm{g}^{-1}$ by the 40th day of storage, while in those treated with both antimicrobials, the counts were lower than this, even after 56 days of storage (Figure 2). In spite of the decrease in bacterial growth rate in sausages treated with nisin in acid solution, a decrease in nisin activity over storage period was also verified. The loss of nisin activity in a meat system was also reported by Cutter and Siragusa (9), who suggested that the diminished activity was due an adsorption of nisin onto meat proteins or lipid particles.

Incorporation of nisin to the surface of meat products seems to be more efficient than its direct addition to the meat mass. Many reports have shown that surface application of nisin by spraying, solution bath or packaging systems is an efficient method in controlling spoilage microorganisms. A reduction in total bacterial counts in fresh veal meat in a cellophane packaging containing nisin was observed by Guerra et al. (20). Martinez et al. (27) verified that spraying a mixture of lactic acid and nisin to beef carcasses can reduce bacterial population by $2 \log$ units. Gill and Holley (17) observed a reduction in the growth of Lactobacillus and Leuconostoc in bologna sausage when a gel containing nisin and lysozyme was applied. However, contrary to what was observed in this study, Castro (4) did not observe an inhibition of lactic acid bacteria growth or a reduction of total aerobic count with the application of Nisaplin ${ }^{\circledR}$ (200 mg/L) in phosphoric acid solution $(0.1 \%)$ to the surface of sausages by dipping in a bath. These differences suggest that nisin retention is higher when incorporated into the sausage casing prior to the stuffing step, as compared to it's application during the postprocess phase in an antimicrobial bath.

\section{CONCLUSION}

The results obtained in this study demonstrate that nisin $(5.0 \mathrm{mg} / \mathrm{L})$ in a phosphoric acid solution $(0.1 \%)$ can be incorporated to the natural casing prior to the stuffing operation to reduce the aerobic plate count and lactic acid bacteria in vacuum packaged sausages stored at low temperature. It was also demonstrated that the hurdle technology is necessary to control spoilage bacteria in vacuum packaged sausages. Since natural casings are used in large quantities in the production of sausages (32) such findings could provide the industry with the option of using nisin in acid phosphoric solution to improve the quality and shelf life of these types of product.

\section{REFERENCES}

1. Ariyapitipun, T.; Mustapha, A.; Clarke, A.D. (1999). Microbial shelf life determination of vacuum-packaged fresh beef treated with polylactic acid, lactic acid, and nisin solutions. J. Food Prot. 62 (8), 913-920.

2. Bell, R.G.; Lacy, K.M. (1986). Factors influencing the determination of nisin in meat products. J. Food Technol., 21, 1-7.

3. Bruns, R.E.; Neto, B.B.; Scarminio, I.S. (1995). Planejamento $e$ Otimização de Experimentos. Editora Unicamp, Campinas.

4. Castro, A.P. (2002). Sobrevivência de bactérias aeróbias mesófilas, psicrotróficas, bactérias láticas e Listeria monocytogenes em salsichas submetidas a tratamento com nisina. São Paulo, Brasil, 91p. (M. Sc Dissertation. Faculdade de Ciências Farmacêuticas. USP).

5. Chollet, E.; Sebti, I.; Martial-Gros, A.; Degraeve, P. (2008) Nisin preliminary study as a potential preservative for sliced ripened cheese: $\mathrm{NaCl}$, fat and enzymes influence on nisin concentration and its antimicrobial activity. Food Control, 19, 982-989.

6. Chung, Y.K.; Vurma, M.; Turek, E.J.; Chism, G.W.; Yousel, A.E. (2005). Inactivation of barotolerant Listeria monocytogenes in sausage by combination of high-pressure processing and food-grade additives. $J$. Food Prot., 68 (4), 744-750.

7. Cooksey, K. (2005). Effectiveness of antimicrobial food packaging materials. Food Additives and Contaminants, 22 (10), 980-987.

8. Cotter, P.D.; Hill, C.; Ross, R.P. (2005) Bacteriocins: Developing innate immunity for food. Nat. Rev. Microbiol, 3, 777-778.

9. Cutter, C.N.; Siragusa, G.R. (1998) Incorporation of nisin into a meat binding system to inhibit bacteria on beef surface. Lett. Appl. Microbiol., 27, 19-23.

10. Davies, E.A.; Milne, C.F.; Bevis, H.E.; Potter, R.W.; Harris, J.M.; Williams, G.C.; Thomas, L.V.; Delves-Broughton, J. (1999). Effective use of nisina to control lactic acid bacterial spoilage in vacuum-packed bologna-type sausage. J. Food Prot. 62 (9), 1004-1010.

11. Dawson, P.L.; Carl, G.D.; Acton, J.C.; Han, I.Y. (2002). Effect of lauric acid and nisin-impregnated soy-based film on the growth of Listeria monocytogenes on turkey bologna. Poult. Sci., 81, 721-726.

12. Deegan, L.H.; Cotter, P.D.; Hill, C.; Ross, P. (2006). Bacteriocins: Biological tools for bio-preservation and shelf-life extension. Int. Dairy J., 16, 1058-1071.

13. Delves-Broughton, J. (2005). Nisin as a food preservative. Food Australia, 57, 525-527. 
14. Delves-Broughton, J. (1990). Nisin and its uses as a food preservative. Food Technol., 100-112.

15. De Martinis, E.C.P.; Alves, V.F.; Franco, B.D.G.M. (2002) Fundamentals and perspectives for the use of bacteriocins produced by lactic acid bacteria in meat products. Food Reviews International, 18 (2 \& 3), 191-208.

16. Geonaras, I.; Skandamis, P.N.; Belk, K.E. Scanga, J.A.; Kendall, P.A.; Smith, G.C.; Sofos, J. (2006). Postprocess control of Listeria monocytogenes on commercial frankfurters formulated with and without antimicrobials and stored at $10^{\circ}$ C. J. Food Prot. 69 (1), 53-61.

17. Gill, A.O.; Holley, R.A. (2000). Surface application of lysozyme, nisin, and EDTA to inhibit spoilage and pathogenic bacteria on ham and bologna. J. Food Prot. 63 (10), 1338-1346.

18. Gill, A.O.; Holley, R.A. (2000). Inhibition of bacterial growth on ham and bologna by lysozyme, nisin and EDTA. Food Research International, 33, 83-90.

19. Grisi, T.C.S.L.; Gorlach-Lira, K. (2005). Action of nisin and high pH on growth of Staphylococcus aureus and Salmonella sp. in pure culture and in the meat of land crab (Ucides cordatus). Braz. J. Microbiol., 36, 151156.

20. Guerra, N.P.; Macías, C.L.; Agrasar, A.T.; Castro, L.P. (2005). Development of a bioactive packaging cellophane using nisaplin ${ }^{\circledR}$ as biopreservative agent. Lett. Appl. Microbiol., 40, 106-110.

21. Guinane, C.M.; Cotter, P.D.; Hill, C.; Ross, R.P. (2005). A Review: Microbial solution to microbial problems; lactococcal bacteriocins for the control of undesirable biota in food. J. Appl. Microbiol., 98, 1316-1325.

22. Hall, P.A.; Ledenbach, L.; Flowers, R.S. (2001). Acid-Producing Microorganisms. In: DOWNES, F.P.; ITO, K. Compendium of Methods for the Microbiological Examination of Foods. Washington: American Public Health Association, p. 201-207.

23. Jofré, A.; Garrida, M.; Aymerich, T. (2008). Inhibition of Salmonella sp. Listeria monocytogenes and Staphylococcus aureus in cooked ham by combining antimicrobials, high hydrostatic pressure and refrigeration. Meat Sci., 78, 53-59.

24. López-Mendoza, M.C.; Ruiz, P.; Mata, C.M. (2007). Combined effects of nisin, lactic acid and modified atmosphere packaging in raw ground pork: Antimicrobials to control Listeria in meat. International Journal of Food Science and Technology 42 (5) 562-566.

25. Lücke, F.K. (2000). Utilization of microbes to process and preserve meat.
Meat Sci., 56, 105-115.

26. Mangalassary, S.; Han, I.; Rieck, J.; Acton, J.; Dawson, P. (2008). Effect of combining nisin and/or lyzozyme with in-package pasteurization for control of Listeria monocytogenes in ready-to-eat turkey bologna during refrigerated storage. Food Microbiol. 25 (7), 866-870.

27. Martinez, Y.B.; Ferrer, K.; Salas, E.M. (2002). Combined effects of lactic acid and nisin solution in reducing levels of microbiological contamination in red meat carcasses. J. Food Prot. 65 (11), 1780-1783.

28. Mauriello, G.; Luca, E.; Storia, L.; Villani, F.; Ercolini, D. (2005). Antimicrobial activity of a nisin-activated plastic film for food packaging. Lett. Appl. Microbiol., 41, 464-469.

29. Morton, R.D. (2001). Aerobic Plate Count. In: DOWNES, F.P.; ITO, K. Compendium of Methods for the Microbiological Examination of Foods. Washington: American Public Health Association, p. 63-67.

30. Parente, E.; Hill, C. (1992). A comparison of factors affecting the production of two bacteriocins from lactic acid bacteria. J. Appl. Bacteriol., 73, 290-298.

31. Raju, C.V.; Shamasundar, B.A.; Udupa, K.S. (2003). The use of nisin as a preservative in fish sausage stored at ambient $\left(28 \pm 2{ }^{\circ} \mathrm{C}\right)$ and refrigerated $\left(6 \pm 2{ }^{\circ} \mathrm{C}\right)$ temperatures. International Journal of Food Science and Technology, 38, 171-185.

32. Santos, E.; Müller, C.M.O.; Laurindo, J.B.; Petrus, J.C.C.; Ferreira, S.R.S. (2008). Technological properties of natural hog casing treated with surfactant solutions. Journal of Food Engineering, 89, 17-23.

33. Siragusa, G.R.; Cutter, C.N.; Willet, J.L. (1999). Incorporation of bacteriocin in plastic retains activity and inhibits surface growth of bacteria on meat. Food Microbiol. 16, 229-235.

34. Sivarooban, T.; Hettiarachchy, N.S.; Johnson, M.G. (2007). Inhibition of Listeria monocytogenes using nisin with grape seed extract on turkey frankfurters stored at 4 and $10^{\circ}$ C. J. Food Prot. 70 (4), 1017-1020.

35. Soriano, A.; Ulmer, H.M.; Scannell, A.G.M.; Ross, R.P.; Hill, C.; García-Ruiz, A.; Arendt, E.K. (2004). Control of food spoiling bacteria in cooked meat products with nisin, lacticin 3147, and a lacticin 3147producing starter culture. Eur. Food Res. Technol., 219, 6-13.

36. Theivendran, S.; Hettiarachchy, N.S.; Johnson, M.G. (2006). Inhibition of Listeria monocytogenes by nisin combined with grape seed extract or green tea extract in soy protein film coated on turkey frankfurters. $J$. Food Sci. 71 (2), 39-44. 